\title{
Epsomite as flame retardant treatment for wood: preliminary study
}

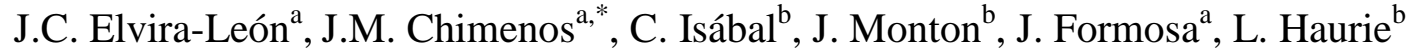 \\ ${ }^{a}$ Departament de Ciència dels Materials i Enginyeria Metal·lúrgica, Universitat de Barcelona, Martí i \\ Franquès, 1, E-08028 Barcelona, Spain \\ ${ }^{\mathrm{b}}$ Departament de Construccions Arquitectòniques II, Universitat Politècnica de Catalunya, Av. Dr. \\ Marañón 44-50, 08028 Barcelona, Spain
}

* Corresponding author. Tel: +34-934 021298; fax: +34-934 035438. E-mail address: chimenos@ub.edu (J.M. Chimenos) 


\section{Abstract}

2 The effect of epsomite as flame retardant for wood has been investigated and compared with a

3 commercial boron salt. Both flame retardants have been introduced into wood samples by vacuum 4 impregnation. Epsomite is a hydrated sulphate salt with a water solubility of $731 \mathrm{~g} \cdot \mathrm{L}^{-1}$ at room 5 temperature. Thanks to this high solubility it was possible to obtain elevated epsomite loadings in 6 comparison with the borax salt. Flame retardancy was evaluated by means of the limiting oxygen 7 index, the dripping test and the exposition to a direct flame (Bunsen test). The results showed that the 8 addition of epsomite increases the limiting oxygen index, delays the time to ignition and the 9 evolution of the temperatures trough the wood.

10

23 Keywords: magnesium sulphate; vacuum impregnation; endothermic decomposition; fire protection; 24 timber. 


\section{Introduction}

Preservation of natural resources and carbon footprint are crucial issues in the present and

3 future of the construction sector. Reports from the EU and the UK indicate that the construction

4 industry is responsible of $40-50 \%$ of the CO2 emissions $[1,2]$. Wood from sustainably managed

5 forests is an environmentally friendly alternative to other construction materials such as concrete or

6 steel [3]. It is a renewable, sustainable and easily workable material that widely used in the building

7 industry for thousands of years, not only as an integral part of structures but also as the main source

8 of furnishings. The British Woodworking Federation affirms that the use of one tonne of timber,

9 instead of other materials, reduces the $\mathrm{CO}_{2}$ emissions in one tonne. Despite this advantages, one of

10 the limitations when using wood as building material is its performance in case of fire. As it is

11 described by White and Dietenberger [4], wood exposed to high temperatures undergoes a thermal

12 degradation that can be divided in several temperature ranges: (i) $100-200^{\circ} \mathrm{C}$ : release of water and non-combustible gases, such as $\mathrm{CO}_{2}$; (ii) $200-300^{\circ} \mathrm{C}$ : pyrolysis of hemicellulose and lignin and

14 production of charred wood; (iii) $300-455^{\circ} \mathrm{C}$ : depolymerisation of cellulose $\left(300-350^{\circ} \mathrm{C}\right)$ and lignin $\left(370-400^{\circ} \mathrm{C}\right)$ and release of flammable gases; and (iv) $>450^{\circ} \mathrm{C}$ : oxidation of the charred wood residue.

Treatment of wood with flame retardants is one of the strategies to increase fire protection.

The aim of flame retardants is to prevent or delay the ignition and to diminish the effects of combustion. Improvement of the behaviour of wood in front of fire can extend the use of timber products in the building sector.

Preservative treatments can be applied to wood by different methods. The nature of the protective agent and the final requirements of the wood product will determine the treatment method.

23 The UNE-EN 351-1 [5] standard describes the classification of preservative penetration and retention 24 of wood and wood-based products. The Spanish Technical Building Code (CTE), in the chapter 25 Structural Safety: Timber structures, describes the usage classes and relates them with the required 
1 level of protection in front of biotic attacks. In the case of fire protection treatments wood products

2 are classified depending on their fire reaction using the UNE EN 13501 standard [6]. Although this

3 standard does not require the evaluation of the penetration depth, the achievement of deeper

4 penetrations are related with higher levels of protection. The protective agent is usually added in

5 liquid form, dispersed or solubilized in a solvent through an impregnation process that involves

6 vacuum and/or pressure cycles to ensure maximum penetration of the chemical agent [7]. Dipping,

7 spray or vapour boron processes are other methods to apply protective treatments to wood, but they

8 usually lead to lower protection depths [8,9].

Boron and phosphorous/nitrogen compounds are among the most common flame retardants used in wood [10-12]. Boron salts create a protective vitreous barrier, which hinders the release of flammable gases and the access of oxygen to wood, while phosphorous-based compounds promote charring and some of them also inhibit the radical combustion reaction [13, 14].

Another important group of flame retardants, widely used in the polymer industry, are the substances that decompose endothermically releasing water vapour or carbon dioxide. These compounds absorb part of the combustion heat and therefore, reduce the temperature of the wood, and the inert gases released dilute the flammable gases in the condensed phase. Among the compounds that decompose endothermically, the magnesium compounds are effective flame retardants and are widely used to increase flame retardancy of polymers [15]. For instance, magnesium hydroxide $\left(\mathrm{Mg}(\mathrm{OH})_{2}\right)$ and basic magnesium carbonates have been used by the authors as flame retardant fillers in poly(ethylene-co-vinyl acetate) (EVA) and polyethylene (PE) [16-19].

21 However, the disadvantage of some of these flame retardants is their limited solubility in water, 22 which is the preferred solvent for the wood impregnation process due to economical and environmental reasons.

As magnesium hydroxide and magnesium carbonates, the hydrated magnesium sulphate 
1 dehydration. The available commercial forms of magnesium sulphate usually occur as hydrates.

2 Specifically the heptahydrate sulphate, also referred to as epsomite or Epsom salt, is the most stable

3 hydrate stage and the only naturally occurring member of the $\mathrm{MgSO}_{4} \cdot \mathrm{nH}_{2} \mathrm{O}$ series. However, unlike

4 the magnesium hydroxide or magnesium carbonates, epsomite is highly soluble in water at room

5 temperature $\left(731 \mathrm{~g} \cdot \mathrm{L}^{-1}\right)$ [20]. This elevated solubility makes possible to obtain a concentrated

6 saturated solution. As far as authors know, the use of epsomite as flame retardant for wood seems

7 uncommon and has been hardly referred in literature [21] and experimental results describing its

8 flame retardancy have not been reported. Therefore this research work is a preliminary study

9 intended to assess the flame retardant effects of this heptahydrate magnesium sulphate

$10\left(\mathrm{MgSO}_{4} \cdot 7 \mathrm{H}_{2} \mathrm{O}\right)$ on wood. The results obtained are compared with those resulting from a commercial

11 hydrated sodium borate, widely used as flame retardant preservative on wood.

\section{Materials and methods}

\subsection{Materials}

Two different species of structural softwoods were chosen from a Spanish timber supplier.

The presence of sapwood and heartwood has great influence on the results, since heartwood has low impregnability than sapwood. For this reason, even if the specimens used contain a mixture of sapwood and heartwood, wood specimens with a higher proportion of heartwood with regard with the other specimens have been discarded. Specimens with knots or other relevant characteristics that could affect significantly the results have also been discarded. They were Scots pine (Pinus Sylvestris L.) with a density of $461 \mathrm{~kg} \cdot \mathrm{m}^{-3}$, and two sets of Black pine (Pinus Nigra) with different densities:

21 Pinus Nigra-A $\left(653 \mathrm{~kg} \cdot \mathrm{m}^{-3}\right)$ and Pinus Nigra-B $\left(574 \mathrm{~kg} \cdot \mathrm{m}^{-3}\right)$. Densities have been measured on wood samples with $12 \%$ of moisture content. The dimensions of the wood specimens were $77 \mathrm{~mm} \mathrm{x}$ $64 \mathrm{~mm} \times 21 \mathrm{~mm}$ with the higher surface in the transverse section. Previous to the impregnation the 24 specimens were dried to constant weight at $103 \pm 2{ }^{\circ} \mathrm{C}$ in an oven. 
The magnesium sulphate used in this research work was a heptahydrate salt $\left(\mathrm{MgSO}_{4} \cdot 7 \mathrm{H}_{2} \mathrm{O}\right.$;

2 epsomite), technical grade, which is commonly used as a fertilizer to correct a magnesium or sulphur deficiency in the soil. Chemical characterization of epsomite was carried out by X-ray fluorescence (XRF) using a Philips PW2400 X-ray sequential spectrophotometer. FRX revealed a content of 29.9\%wt $\mathrm{SO}_{3}$ and $15.7 \%$ wt $\mathrm{MgO}$ and a loss on ignition (LOI) at $1000{ }^{\circ} \mathrm{C}$ of $54.3 \%$ wt. $\mathrm{A}$ small content of $\mathrm{CaO}$ lower than $0.05 \%$ wt, probably from a calcium sulphate, was also determined. Thermogravimetric analysis (TGA) of the epsomite (Fig. 1) was performed on a TA Instruments SDT Q600 Simultaneous TGA-DSC equipment, in air atmosphere (flow rate of $100 \mathrm{~mL} \cdot \mathrm{min}^{-1}$ ) with a continuous heating rate of $10^{\circ} \mathrm{C} \cdot \mathrm{min}^{-1}$ and a sample mass of $35.0 \pm 0.5 \mathrm{mg}$. The sample was previously stabilised at $30^{\circ} \mathrm{C}$ and heated up to $1300{ }^{\circ} \mathrm{C}$. The shape of the TGA curve shows that the mass loss occurs in several steps. This is clearly showed by the derivative of the TGA curve (DTG), dashed line in Fig. 1. One or more water molecules were released in several steps during the occur gradually between 60 and $303{ }^{\circ} \mathrm{C}$, with a total water mass loss around $51.3 \%$ wt. In the range of 896 and $1148{ }^{\circ} \mathrm{C}$ anhydrous magnesium sulphate decomposes to $\mathrm{MgO}(17.0 \% \mathrm{wt})$ and releases $\mathrm{SO}_{3}$ (31.7\%wt), corroborating the results previously obtained by XRF. Moreover, differential scanning calorimetry (DSC) was simultaneously determined by the same thermal decomposition experiments to measure the heat flow associated with the thermal decomposition (Fig. 2). In this case, the heat flow signal was corrected by taking into account the sample's mass at each temperature. The dehydration process requires $1977 \mathrm{~J} \cdot \mathrm{g}^{-1}$ as it is shown in Fig. 2 by the integration of endothermic peaks between $36-303^{\circ} \mathrm{C}$. This value of heat of dehydration is much higher than other hydrated inorganic salts commonly used as fire retardants, such as aluminium hydroxide $\left(1170 \mathrm{~J}^{-\mathrm{g}^{-1}}\right)$ or magnesium hydroxide $\left(1244 \mathrm{~J} \cdot \mathrm{g}^{-1}\right)$. Moreover, the water content per mass unit is also much higher in epsomite (51.2\%wt vs. 34.6\%wt and 31.0\%wt, respectively) [13]. 
2 from Riotinto Minerals, also known as borax $5 \mathrm{~mol}$, widely used as fire retardant preservative, was used in this study for comparative purposes. It starts to dehydrate at about $65^{\circ} \mathrm{C}$ and loses all water of hydration when heated above $320^{\circ} \mathrm{C}$. Notice that this dehydration temperature range is very similar to epsomite dehydration range.

\subsection{Impregnation method}

Just before vacuum impregnation, saturated solutions of $\mathrm{MgSO}_{4} \cdot 7 \mathrm{H}_{2} \mathrm{O}\left(1.23 \mathrm{~g} \cdot \mathrm{mL}^{-1}\right)$ or

$8 \mathrm{Na}_{2} \mathrm{~B}_{4} \mathrm{O}_{7} .5 \mathrm{H}_{2} \mathrm{O}\left(1.03 \mathrm{~g} \cdot \mathrm{mL}^{-1}\right)$ were prepared at room temperature. Saturated salt solutions were 9 prepared using deionized water and filtered to eliminate any non-dissolved salt crystals. Impregnation was performed in a vacuum-autoclave of a diameter of $45 \mathrm{~cm}$ and a height of $150 \mathrm{~cm}$. For each experimental conditions and fire resistant test method proposed, wood specimens were completely immersed in triplicate in the saturated solution and afterwards vacuum was applied (20 - 10 mbar; $15-7 \mathrm{mmHg}$ ) during $22 \mathrm{~h}$. Although impregnation of only three specimens not allows to determine the variability of a wood species regarding the impregnability, for a preliminary study it is enough to give indications about effectiveness of the process. The impregnation treatment consisted of two vacuum cycles in order to extract the maximum air from wood cavities, and permeate and distribute the maximum amount of flame retardant solution through the interior of the wood.

After impregnation process, specimens were initially drained and then dried in an oven at 35

$20 \pm 2{ }^{\circ} \mathrm{C}$ to constant weight. Low drying temperature was selected to avoid losing the first hydration water molecule of epsomite (see Fig. 1). Subsequently, and before to evaluate the fire retardant performance of wood treated, the magnesium sulphate (or sodium borate) precipitated on the surface of specimens was removed using a soft brush. In order to determine the remaining moisture of the wood samples dried at $35^{\circ} \mathrm{C}$, there were used blank wood samples impregnated only with water. In 
all cases moisture was between 5 to $6 \%$, which was taken into consideration to calculate the amount of flame retardant retained.

\subsection{Test methods}

Scanning electron microscopy (SEM) has been used to verify the presence and distribution of the flame retardant in the wood cells. The fire behaviour of the treated samples was evaluated using three different fire tests: dripping test, limiting oxygen index (LOI) and Bunsen burner test.

\subsubsection{SEM}

Samples of $20 \mathrm{~mm} \times 20 \mathrm{~mm} \times 3 \mathrm{~mm}$ were cut from each wood sample and they were observed in a high resolution low-vacuum FEI Quanta 200 SEM equipment. In order to obtain these micrographs the specimens were previously chipped by means of a blow with a hammer and a chisel. In this chipping process part of the impregnated epsomite could fell out of the cell lumen. Therefore, it is not intended to determine the overall distribution by means of SEM observation.

\subsubsection{Dripping test}

A radiator device described in the Spanish UNE 23.725-90 standard [22] was employed to measure the degree of extinguish ability of combustion. Impregnated specimens $(77 \mathrm{~mm}$ x $64 \mathrm{~mm} \times$ $21 \mathrm{~mm}$ ) are placed on a metallic grid $300 \mathrm{~mm}$ below a heat source of $500 \mathrm{~W}$, which is taken away and put back after each ignition and extinction. Three specimens for each flame retardant formulation were tested and the parameters determined were the number of ignitions (No), the time at which the first ignition occurs $\left(\mathrm{t}_{0}\right)$ and the average time of flame persistence during the first 5 min of combustion $\left(\mathrm{t}_{\mathrm{m}}\right)$.

\subsubsection{Limiting Oxygen of Index (LOI)}

The Limiting Oxygen Index (LOI) was determined following UNE-EN ISO 4589 [23]. Although LOI test primarily was developed for plastics, this method has been successfully used to 
1 determine fire performance of wood [24]. The ISO 4589 standard establishes the test procedure to

2 determine the LOI on vertically oriented small specimens, in this case of $70 \mathrm{~mm} \times 10 \mathrm{~mm} \times 1 \mathrm{~mm}$,

3 under a mixture of nitrogen and oxygen flow. LOI is the minimum concentration of oxygen at which

4 a specimen will support combustion under the criteria defined in the standard.

\subsubsection{Bunsen burner test.}

This relatively simple test for evaluating the effectiveness of flame retardants involves exposing the specimens of treated wood to a Bunsen flame for a certain period of time. It is based upon a flammability test for thermoplastic elastomers intumescent products described by Abu-Isa in

9 the bibliography [25]. A scheme of the device is shown in Fig. 3. The apparatus includes a three-wall

10 steel to form a square-shaped chamber with an open side (front). The wood sample is placed on top of the walls and the burner is adjusted during each test so that the tip of the blue cone of the flame touches the lower surface of the test specimens. Three thermocouples were affixed in the wood specimen to monitor temperatures in the exposed and non-exposed surface during the test: a thermocouple was placed at the central position of the lower surface and other two at the central and external position of the upper surface (see Fig. 3). This test records the evolution of temperature in front of time on the non-exposed surface of the samples. Although it is not related to the EN 13501 standard [6], the Bunsen burner test gives information about the effectiveness regarding fire reaction.

\section{Results and discussion}

The flame retardant loading was determined by weight differences between the dry weight of specimens after impregnation and before impregnation. As it was aforementioned, the moisture content of wood samples after drying at $35^{\circ} \mathrm{C}$ was $5-6 \%$. Therefore, this residual moisture content has been subtracted to determine the retained percentage of flame retardant. The mean flame retardant loading (FRL;\%wt) is shown in Table 1 (average). Although the three replicates showed

24 similar FRL more replicates would be necessary to perform an extensive study on the impregnation 
process. As can be observed, the amount of both flame retardant chemicals follows the same trend,

2 i.e. both Pinus Nigra retain higher amounts of preservative than Pinus Sylvestris. Between both Pinus

3 Nigra the sample with lower density (Pinus Nigra-B) exhibits higher retentions than Pinus Nigra-A.

4 These differences in the impregnation results can only be related to the internal structure of the tested

5 specimens. Besides, in all cases it can be observed a great difference in the degree of impregnation

6 obtained with epsomite and borax. As expected, the large difference in solubility between both

7 products allows obtaining saturated solutions with higher amount of epsomite than borax 5 mol.

8 Therefore, for the same impregnation process, the amount of epsomite permeated is higher than the 9 amount of borax 5 mol.

Fig. 4 shows the micrograph of a radial section of the Pinus Nigra-B impregnated with a saturated solution of epsomite, once the specimen has been dried at $35^{\circ} \mathrm{C}$. As it can be seen, the wood cells (tracheids and rays) are fully loaded with an inorganic salt. The characterization of this solid (yellow square in Fig. 5a) by energy-dispersive X-ray spectroscopy (EDS) shows the presence of $\mathrm{O}, \mathrm{Mg}$ and $\mathrm{S}$ (Fig. 5b) as major elements, corresponding to magnesium sulphate contained in the cells of wood. A micrograph of the same type of wood impregnated with borax 5 mol can be seen in Fig. 6a. The EDS analysis of one of the particles that can be distinguished in Fig. 6a is depicted in Fig. 6b. The presence of sodium in the EDS analysis confirms the permeation of borax 5 mol. However, as it can be observed, in this case the cells are not saturated with flame retardant due to the lower amount permeated into the sample.

However, this amount of epsomite may be too large for certain application (i.e. beams, joists, studs, roofing, etc.) where the weight of the treated wood is essential to determine their mechanical

22 properties and the criteria selection. In these cases, the amount of epsomite loaded can be adjusted 23 diminishing the concentration of magnesium sulphate in the impregnation solution. Moreover, 24 because epsomite has a high solubility and diffusivity, this fire retardant preservative can move out 
1 of a piece of wood under severe wetting. Hence, epsomite-treated wood should only be used where it

2 is protected from major water exposure.

\subsection{Dripping test}

Table 2 shows the average results of the main parameters obtained with this test: the first time

5 of ignition, the number of ignitions and the average time of flame persistence. The goal in this test is

6 to develop materials that do not exhibit any ignition when exposed to the heating source. If ignition

7 occurs, it is preferred that the flames appear at longer times and that they do not persist onto the 8 sample.

As it can be seen in Table 2 the untreated wood samples exhibit lower times to ignition and longer average combustion times compared with the wood samples containing flame retardants.

11 Among the different wood types it should be noticed that the Pinus Nigra-A shows a remarkably

12 longer length of flame persistence, both for the untreated sample and the treated ones. This behaviour

13 could be related with the presence of duramen, which is hardly impregnable, and resin in the Pinus

14 Nigra-A samples.

Regarding the results obtained with the treated wood, both fire retardant chemicals significantly improve the fire behaviour of all specimens. Noteworthy, epsomite increased the time to ignition $\left(\mathrm{t}_{0}\right)$ by $56 \%$ to $200 \%$ in comparison with the untreated wood. Epsomite acts through an

18 endothermic effect, as other hydrated compounds, lowering the temperature of the material near the

19 flame during their endothermic decomposition and diluting the flammable gases with the release of 20 water [13]. As a result, the wood is cooled and the time to ignition is increased. According to that, 21 the increase in the time required for the first ignition $\left(t_{0}\right)$ is related to the amount of epsomite loaded 22 and therefore, the heat involved the dehydration process of the seven molecules of water of 23 crystallization. 
However, depending of the type of wood, the auto-extinguishing ability $\left(\mathrm{t}_{\mathrm{m}}\right)$ was not so

2 different between both used fire retardant chemicals. Several mechanisms can be involved in the auto-extinguish process depending on the fire retardant chemical used, and probably two or more of them may be feasible in a given case $[13,26]$. While the water vapour provided by hydrated

5 inorganic salts dilutes the flammable gases produced by wood to prevent the formation of a 6 flammable mixture, borax form glassy films on exposure to high temperature, which serves as an 7 insulating blanket and reduces the volatile products.

\subsection{Limiting Oxygen of Index (LOI)}

The average results of limiting oxygen indices (LOI) are shown in Table 3. As it is expected the LOIs values of wood specimens increase after being treated with flame retardants. High loaded epsomite samples experience a remarkable LOI enhancement up to $27 \%$, while the impregnation with borax 5 mol causes only a moderate increase with regard to untreated wood. Probably the differences in the amount of flame retardant loading highly affect the LOI values.

\subsection{Bunsen burner test}

Non-treated wood specimens showed very similar evolution of the temperatures on the nonexposed surface of the specimens tested. Therefore, and in order to make easier the visualization of the results of the treated samples in the graphs only appears the curve of the untreated Pinus Nigra-B. Fig. 7 shows the evolution of temperatures in the non-exposed surface in front of time for the different wood samples treated with epsomite. Since results were very similar among replicates, only the temperature profile of one of the replicas is shown in the figure. In all cases, around $70{ }^{\circ} \mathrm{C}$ it can be observed a plateau where the temperatures remain constant for a period of time, after which the temperatures rise with a stronger slope. The wood without flame retardant treatment has a shorter plateau and the thermocouple reaches $150^{\circ} \mathrm{C}$ in approximately 15 mintues. The presence of epsomite results in a remarkable enhancement of the length of the plateau and therefore there is a delay in the 
1 increase of temperatures on the non-exposed surface. Epsomite treated samples did not reach $150{ }^{\circ} \mathrm{C}$

2 after 30 minutes of test, in the case of the Pinus Nigra-A the temperature at 30 minutes was still 3 below $110^{\circ} \mathrm{C}$.

4 This phenomenon was also observed in other fireproofing materials containing hydrated 5 minerals that decompose endothermically [27, 28]. This mechanism of evaporation and condensation 6 of water takes place in the hot area and the cold area, respectively, and it progresses from the heat 7 focus of the surface exposed to the flame to the non-exposed surface. As the temperature was 8 recorded on the non-exposed surface, the temperature of this plateau was under $100^{\circ} \mathrm{C}$ as a 9 consequence of the thermal equilibrium (convection and radiation), which is produced between the 10 non-exposed surface and the ambient [27].

The specimens treated with borax $5 \mathrm{~mol}$ did not show an improvement in this test compared to the non-treated wood samples. Fig. 8 shows the evolution of temperatures on the non-exposed 13 surface for the different samples of Pinus Nigra-A. As it can be observed the sample treated with borax 5 mol undergoes a similar behaviour as the untreated sample. Probably at low flame retardant loading, $7 \% \mathrm{wt}$ in this case, the formation of a protective glassy film is not to delay the combustion under the conditions of the Bunsen test.

\section{Conclusions}

The high solubility of epsomite in water at room temperature makes possible to treat wood samples without heating and without using organic solvents. Using a vacuum impregnation process it

20 is possible to obtain wood samples permeated with large amounts of this heptahydrate salt into the 21 internal structure of wood, up to $412 \mathrm{~kg} \cdot \mathrm{m}^{-3}$ of epsomite in a Pinus Nigra wood sample. The 22 epsomite loading could be probably increased using a vacuum-pressure impregnation system, or 23 decreased by adjusting the concentration of epsomite in the solution impregnated. Given its high 
1 solubility and non-toxicity, epsomite could be an interesting alternative to improve the fire behaviour

2 of indoor wood panelling and structural timber elements.

According to the results of this preliminary study, the effectiveness of epsomite as a flame

4 retardant preservative has been demonstrated using three fire tests, which have allowed assessing the

5 improvement on the fire behavior of the specimens impregnated with epsomite. Epsomite undergoes

6 an endothermic dehydration with an associated heat of $1977 \mathrm{~J} \cdot \mathrm{g}^{-1}$ and a release of water of $51.2 \%$ wt.

7 Therefore, epsomite acts as a heat sink lowering the temperature of the material near the flame and

8 delaying the ignition of treated wood. Moreover, the great amount of water generated from the

9 dehydration process, which is involved in the vaporization-condensation mechanism, keeps the

10 temperature of the area immediately around of flame below $100^{\circ} \mathrm{C}$, increasing the insulation capacity

11 of the impregnated wood.

In this study the amounts of borax permeated into the wood using the same impregnation process where significantly lower than for the epsomite. However, since boron salts act trough a

14 different flame retardant mechanism, mainly forming a protective glassy film that hinders the

15 penetration of oxygen into the condensed phase, it could be interesting to evaluate possible 16 synergistic effects with epsomite.

\section{Acknowledgments}

The author would like to thank Magnesitas Navarras, S.A. for their financial support and

19 Fustes Borniquel and Forestal Catalana S.A. for providing the wood samples. The authors would like

20 to thank the Catalan Government for the quality accreditation given to their research groups

21 DIOPMA (2014 SGR 1543) and GICITED (2014 SGR 1298), and also the MINECO for the project

22 BIA2014-52688-R. 
2 [1] L. Wang, A. Toppinen, H. Juslin, Use of wood in green building: a study of expert perspectives

3 from the UK. Journal of Cleaner Production 65 (2014) 350-361.

4 [2] M. P. Mercader, A. Ramírez de Arellano, M. Olivares, Model for quantifying CO2 emissions in 5 buildings due to material resources consumed during construction. Informes de la Construcción $6 \quad 64: 527(2012)$ 401-414.

7 [3] R. Sathre, L. Gustavsson. Using wood products to mitigate climate change: External costs and 8 structural change. Applied Energy 86 (2009) 251-257

9 [4] R.H. White, M.A. Dietenberger. Wood products: thermal degradation and fire. Encyclopedia of 10 Materials: Science and Technology. Elsevier Science Ltd. (2001) 9712-9716

11 [5] UNE-EN 351-1:2008. Durability of wood and wood-based products - Preservative-treated solid 12 wood - Part 1: Classification of preservative penetration and retention. Aenor. Madrid. (2008).

13 [6] UNE-EN 13501-5:2007. Fire classification of construction products and building elements - Part 14 5: Classification using data from external fire exposure to roofs tests. Aenor. Madrid. (2007)

[7] Z. Bednarek, A. Kaliszuk-Wietecka. Analysis of the fire-protection impregnation influence on 16 wood strength. Journal of Civil Engineering and Management. Journal of Civil Engineering and 17 Management 13:2(2007) 79-85.

18 [8] L.J. Russell, D.C.O. Marney, D.G. Humphrey, A.C. Hunt, V.P. Dowling, L.J. Cookson.

19 Combining fire retardant and preservative systems for timber products in exposed applications - state 20 of the art review. Australian Government. Forest and Wood Products Research and Development 21 Corporation. Victoria, Australia. (2007).

22 [9] Ku. Tsunoda. Preservative properties of vapor-boron-treated wood and wood-based composites. J 23 Wood Sci 47 (2001) 149-153.

24 [10] N. Ayrilmis, T. Dundar, Z. Candan, T. Akbulut. Wettability of fire retardant treated laminated 25 veneer lumber (LVL) manufactured from veneers dried at different temperatures. Bioresources 4 26 (2009) 1536-1544.

27 [11] D.C.O. Marney, L.J. Russel. 1Combined Fire Retardant and Wood Preservative Treatments for 28 Outdoor Wood Applications - A Review of the Literature. Fire Technology 44 (2008) 1-14.

29 [12] J. Jiang, J. Li, J. Hu, D. Fan, Effect of nitrogen phosphorus flame retardants on thermal 30 degradation of wood. Construction and Building Materials 24 (2010) 2633-2637.

31 [13] L.A. Lowden, R. Hull. Flammability behaviour of wood and a review of the methods for its 32 reduction. Fire Science Reviews 2:4 (2013) 1-19.

33 [14] Q. Wang, J. Li, J. E. Winandy. Chemical mechanism of fire retardance of boric acid on wood. 34 Wood Sci Technol 38 (2004) 375-389. 
Magnesium Compounds on Thermal Degradation Behavior of Red Gum Wood. Materials 7 (2014)

[16] L. Haurie, A.I. Fernández, J.I. Velasco, J.M. Chimenos, J.R. Ticó-Grau, F. Espiell. Synthetic hydromagnesite as flame retardant. A study of the stearic coating process. Macromol. Symp. 221 (2005) 165-174.

[17] L. Haurie, A.I. Fernández, J.I. Velasco, J.M. Chimenos, J.M. Lopez Cuesta, F. Espiell. Synthetic hydromagnesite as flame retardant. Evaluation of the flame behavior in polyethylene matrix. Polym.

9 Degrad. Stabil. 91 (2006) 989-994.

[18] L. Haurie, A.I. Fernández, J.I. Velasco, J.M. Chimenos, J.M. Lopez Cuesta, F. Espiell. Thermal stability and flame retardancy of LDPE/EVA blends filled with synthetic hydromagnesite/aluminium hydroxide/montmorillonite mixtures. Polym. Degrad. Stabil. 92 (2007) 1082-1087.

[19] A.I. Fernández, L. Haurie, J. Formosa, J.M. Chimenos, M. Antunes, J.I. Velasco.

Characterization of poly(ethylene-co-vinyl acetate) (EVA) filled with low grade magnesium hydroxide. Polym. Degrad. Stabil. 94 (2009) 57-60.

[20] D.R. Lide (Ed.). Handbook of Chemistry and Physics. $86^{\text {th }}$ ed. Boca Raton, Florida: CRC Press 17 Inc., (2005).

[21] A. Unger, A.P. Schniewind, W. Unger. Conservation of wood artifacts: A handbook. Springer-

[24] R. H. White. Oxygen Index Evaluation of Fire-Retardant-Treated Wood. Wood Science 12:2 (1979) 113-121

[25] I.A. Abu-Isa. Intumescent Thermoplastic Elastomer Fire Shield Material. SAE 2002 World Congress, Detroit, MI. Society of Automotive Engineers, Inc. (2002).

[26] M. Nikolaeva, T. Kärki. A review of fire retardant processes and chemistry, with discussion of the case of wood-plastic composites. Balt. For. 17 (2011) 314-326.

[27] C. Leiva, L.F. Vilches, J. Vale, C. Fernández-Pereira. Fire resistance of biomass ash panels used for internal partitions in buildings. Fire Safety J. 44 (2009) 622-628.

[28] J. Formosa, J.M. Chimenos, A.M. Lacasta, L. Haurie, J.R. Rosell. Novel fire-protecting mortars 
Table 1. Flame retardant loading for each wood sample.

2

\begin{tabular}{lcc}
\cline { 2 - 3 } & $\begin{array}{c}\text { Epsomite } \\
\left(\mathrm{MgSO}_{4} \cdot 7 \mathrm{H}_{2} \mathrm{O}\right)\end{array}$ & $\begin{array}{c}\text { Borax 5 mol } \\
\left(\mathrm{Na}_{2} \mathrm{~B}_{4} \mathrm{O}_{7} \cdot 5 \mathrm{H}_{2} \mathrm{O}\right)\end{array}$ \\
\cline { 2 - 3 } & FRL $(\mathrm{wt} \%)$ & $\mathrm{FRL}(\mathrm{wt} \%)$ \\
\hline Pinus Sylvestris & 46 & 3 \\
Pinus Nigra-A & 55 & 7 \\
Pinus Nigra-B & 78 & 9 \\
\hline
\end{tabular}

3

4 
1 Table 2. Dripping test results. Number of ignitions (No); time at which the first ignition occurs $\left(\mathrm{t}_{0}\right)$;

2 average time of flame persistence $\left(t_{m}\right)$.

\begin{tabular}{ccccccccc}
\hline \multicolumn{2}{c}{ Untreated specimens } & \multicolumn{3}{c}{$\begin{array}{c}\text { Borax 5 mol } \\
\left(\mathrm{Na}_{2} \mathrm{~B}_{4} \mathrm{O}_{7} \cdot 5 \mathrm{H}_{2} \mathrm{O}\right)\end{array}$} & \multicolumn{3}{c}{$\begin{array}{c}\text { Epsomite } \\
\left(\mathrm{MgSO}_{4} \cdot 7 \mathrm{H}_{2} \mathrm{O}\right)\end{array}$} \\
\hline No & $\mathrm{t}_{0}(\mathrm{~s})$ & $\mathrm{t}_{\mathrm{m}}(\mathrm{s})$ & $\mathrm{No}$ & $\mathrm{t}_{0}(\mathrm{~s})$ & $\mathrm{t}_{\mathrm{m}}(\mathrm{s})$ & $\mathrm{No}$ & $\mathrm{t}_{0}(\mathrm{~s})$ & $\mathrm{t}_{\mathrm{m}}(\mathrm{s})$ \\
\hline 8 & 34 & 24 & $\# 31$ & 35 & 5 & $\# 18$ & 53 & 11 \\
$\# 2$ & 29 & 205 & $\# 5$ & 37 & 54 & $\# 5$ & 87 & 35 \\
$\# 15$ & 46 & 12 & $\# 23$ & 68 & 4 & $\# 14$ & 115 & 5 \\
\hline
\end{tabular}

5 
1 Table 3. Limiting Oxygen Index (LOI) values obtained

2

\begin{tabular}{lccc}
\cline { 2 - 4 } & \multicolumn{3}{c}{ LOI (\%) } \\
\cline { 2 - 4 } & $\begin{array}{c}\text { Untreated } \\
\text { specimens }\end{array}$ & $\begin{array}{c}\text { Borax 5 mol } \\
\left(\mathrm{Na}_{2} \mathrm{~B}_{4} \mathrm{O}_{7} \cdot 5 \mathrm{H}_{2} \mathrm{O}\right)\end{array}$ & $\begin{array}{c}\text { Epsomite } \\
\left(\mathrm{MgSO}_{4} \cdot 7 \mathrm{H}_{2} \mathrm{O}\right)\end{array}$ \\
\hline Pinus Sylvestris & 25.1 & 26.0 & 41.1 \\
Pinus Nigra-A & 24.0 & 29.1 & 41.5 \\
Pinus Nigra-B & 26.0 & 30.5 & 53.5 \\
\hline
\end{tabular}

3

4

5

6 


\section{Figure Captions.}

2 Figure 1. Thermogravimetric analysis (TGA) and derivative of the TGA curve (DTG) of the

3 epsomite $\left(\mathrm{MgSO}_{4} \cdot 7 \mathrm{H}_{2} \mathrm{O}\right)$ up to $1200^{\circ} \mathrm{C}$.

4 Figure 2. Differential scanning calorimetry (DSC) of the epsomite $\left(\mathrm{MgSO}_{4} \cdot 7 \mathrm{H}_{2} \mathrm{O}\right)$ in air atmosphere $5 \quad\left(100 \mathrm{~mL} \cdot \mathrm{min}^{-1}\right)$ with a heating rate of $10^{\circ} \mathrm{C} \cdot \mathrm{min}^{-1}$.

6 Figure 3. Bunsen burner test apparatus.

7 Figure 4. Environmental scanning electron microscopy (ESEM) micrograph of the radial section of 8 the Pinus Nigra-B impregnated with a saturated solution of epsomite $\left(\mathrm{MgSO}_{4} \cdot 7 \mathrm{H}_{2} \mathrm{O}\right)$.

9 Figure 5. a) ESEM micrograph of the radial section of Pinus Nigra-B impregnated with epsomite and

10 b) Energy-dispersive X-ray spectroscopy (EDS) of flame retardant chemical loaded into the treated 11 wood.

12 Figure 6. a) ESEM micrograph of the radial section of Pinus Nigra-B impregnated with borax 5 mol 13 and b) Energy-dispersive X-ray spectroscopy (EDS) of the flame retardant chemical loaded into the 14 treated wood.

15 Figure 7. Temperatures recorded in the central position of the non-exposed surface for the untreated 16 specimen and for the specimens impregnated with epsomite.

17 Figure 8. Temperatures recorded in the central position of the non-exposed surface for the untreated 18 Pinus Nigra-A and impregnated with epsomite and borax 5 mol. 


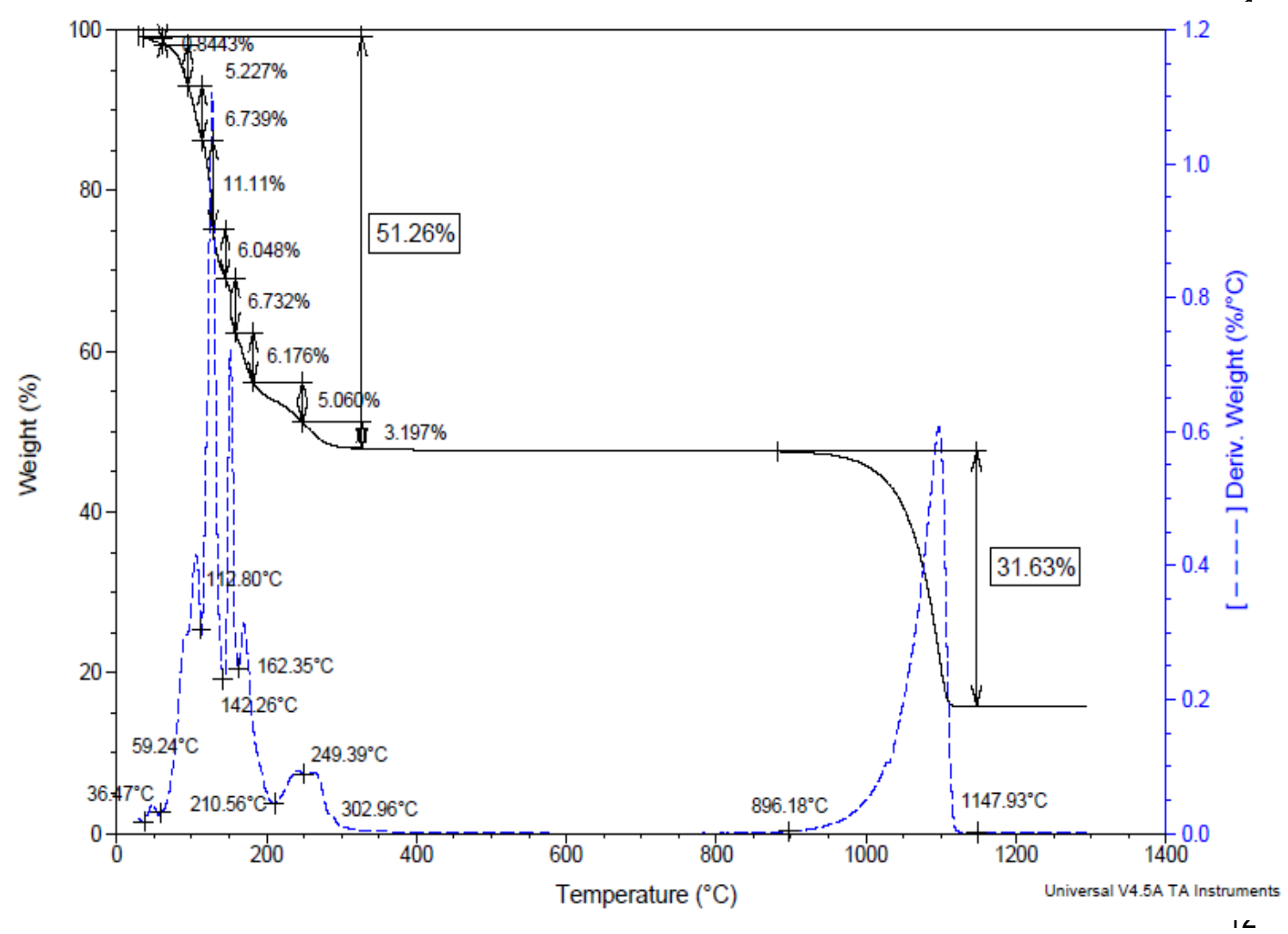

Figure 1.

J.C. Elvira-León et al. 


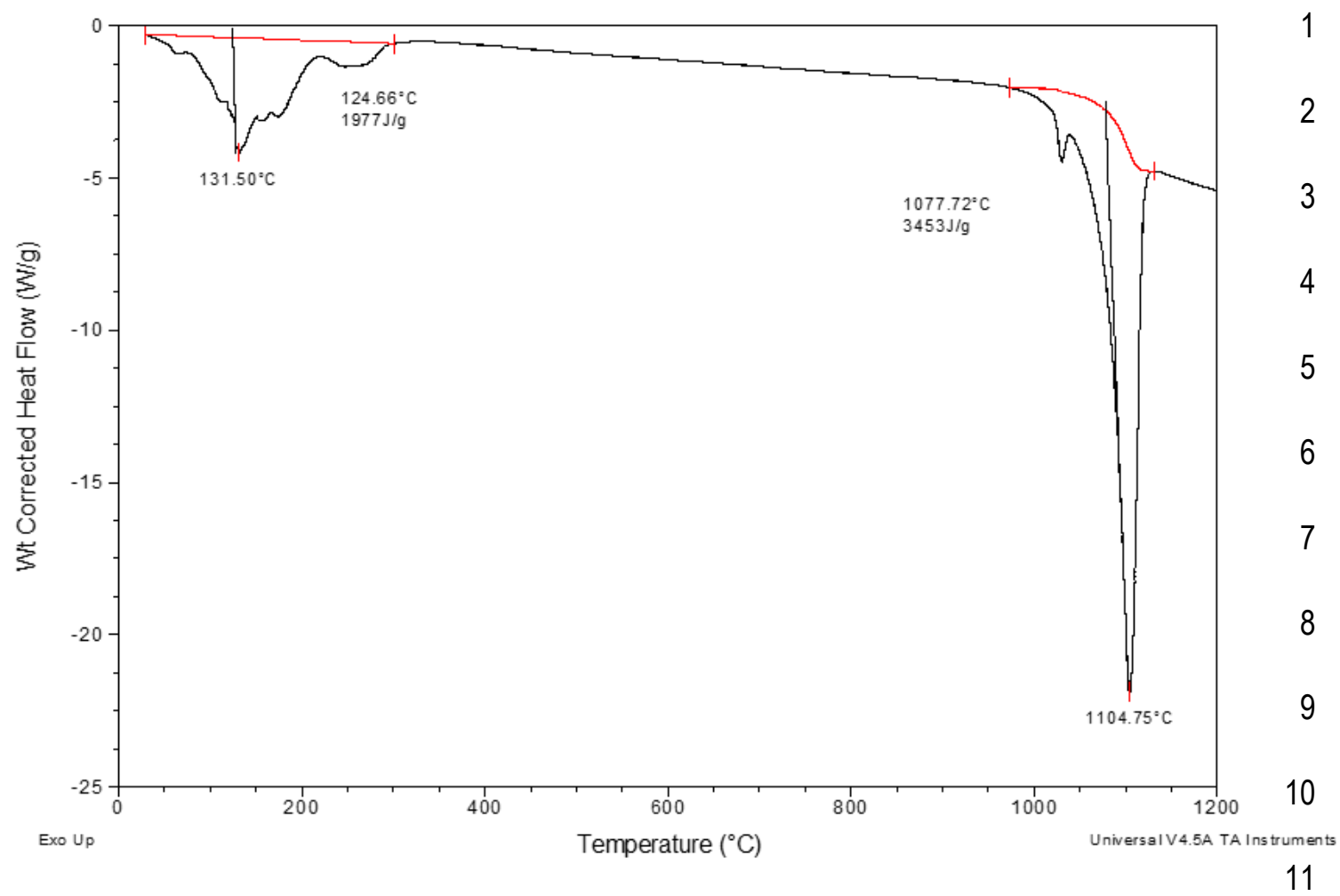

Figure 2.

J.C. Elvira-León et al.

14 
3

4

5

6

7

8

9

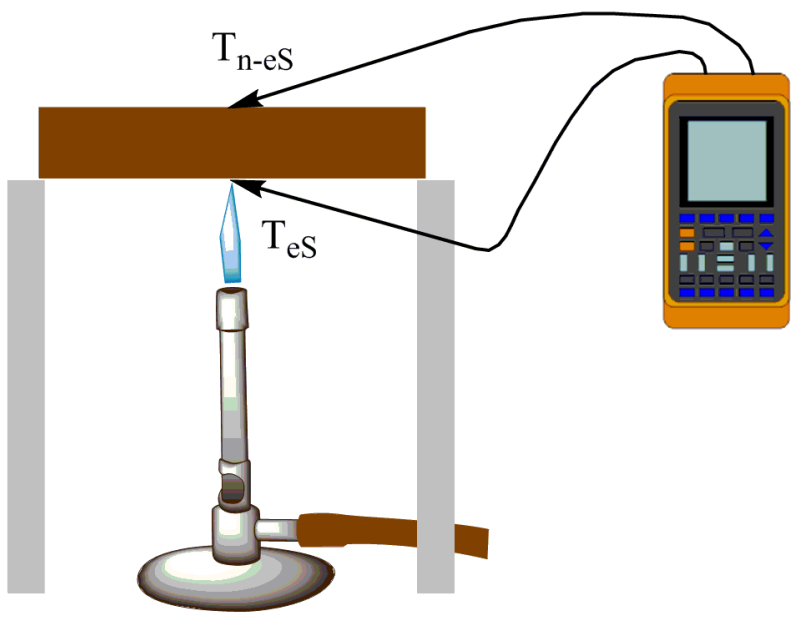

Figure 3.

J.C. Elvira-León et al. 


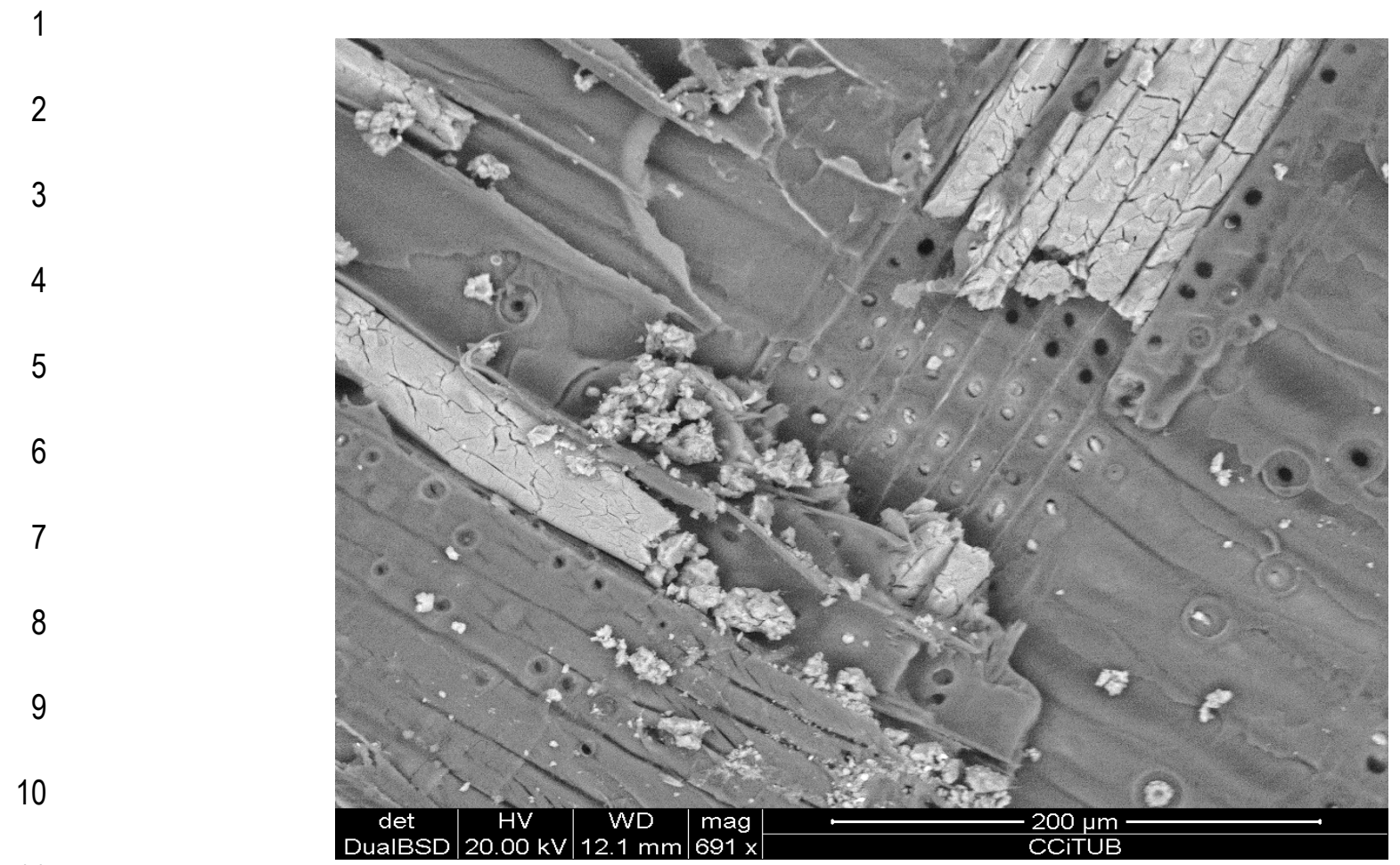

Figure 4.

J.C. Elvira-León et al. 

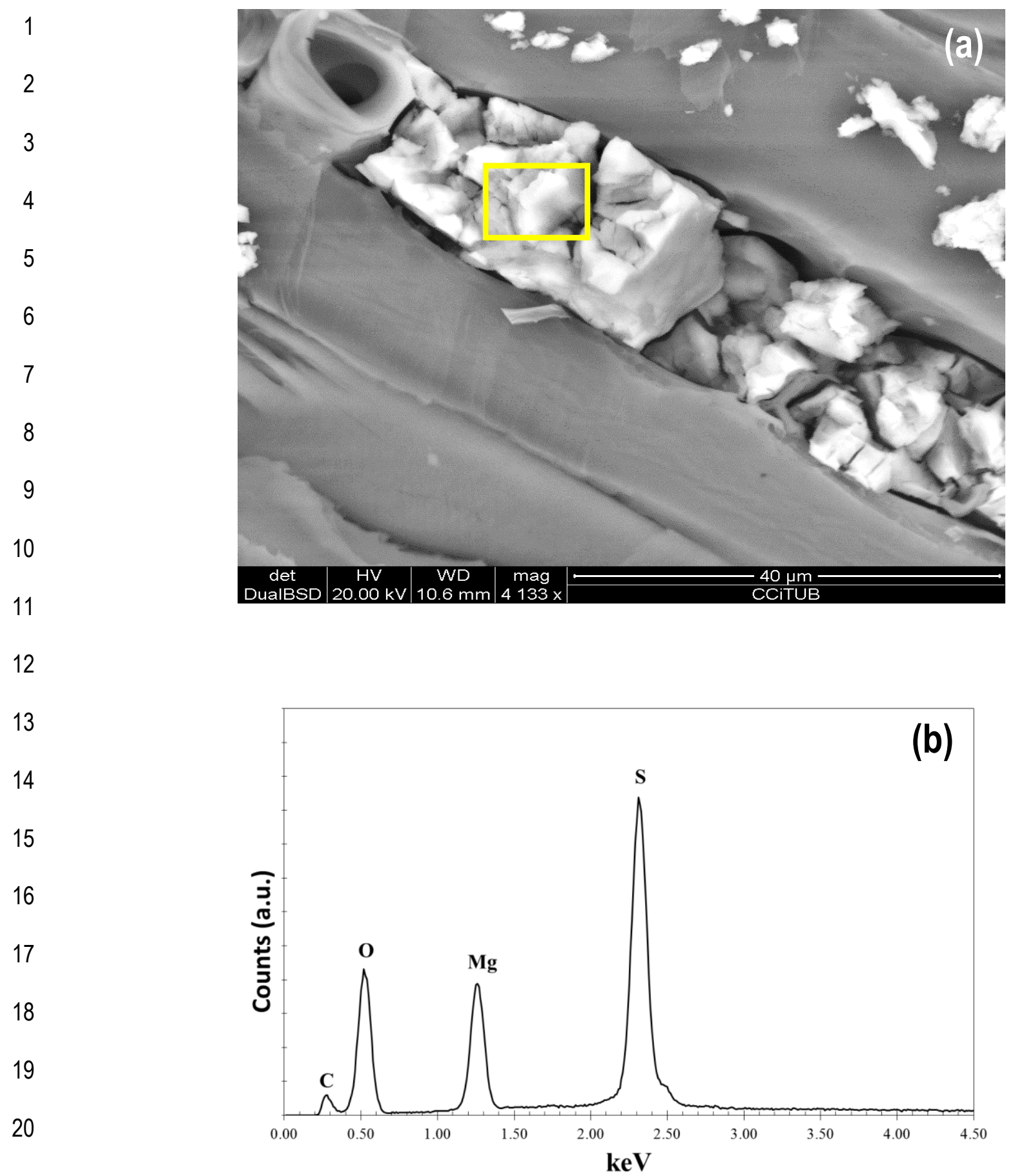

Figure 5.

J.C. Elvira-León et al. 


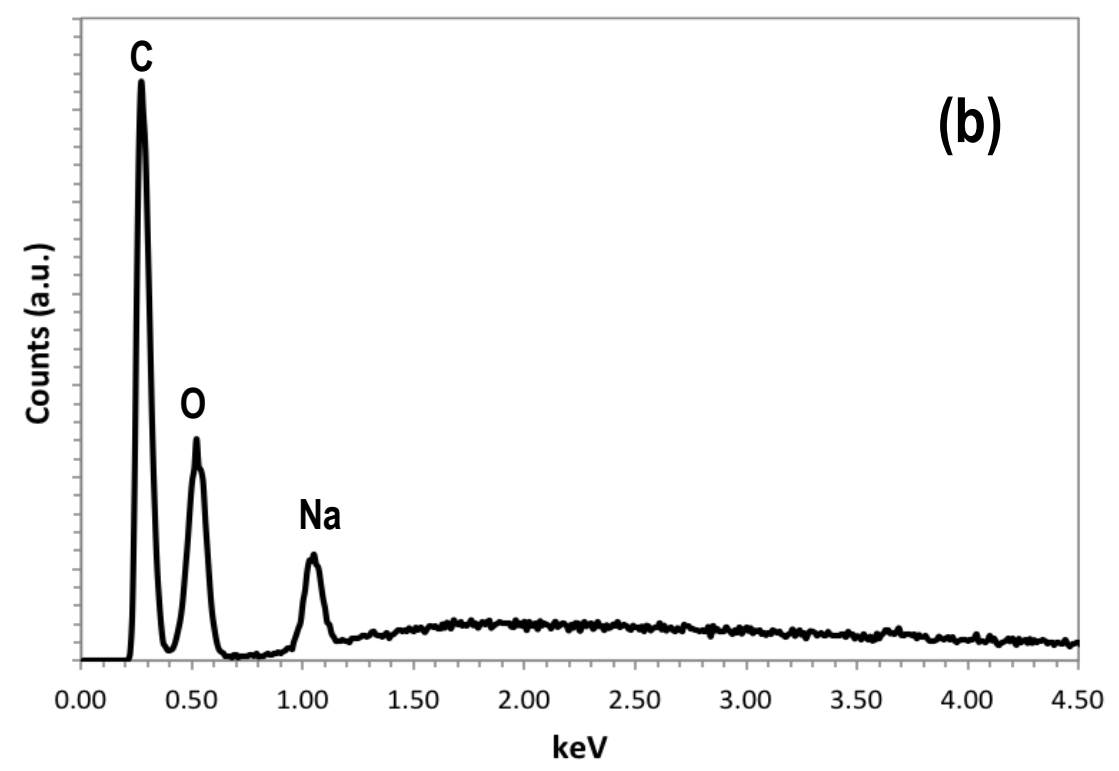

Figure 6.

J.C. Elvira-León et al. 


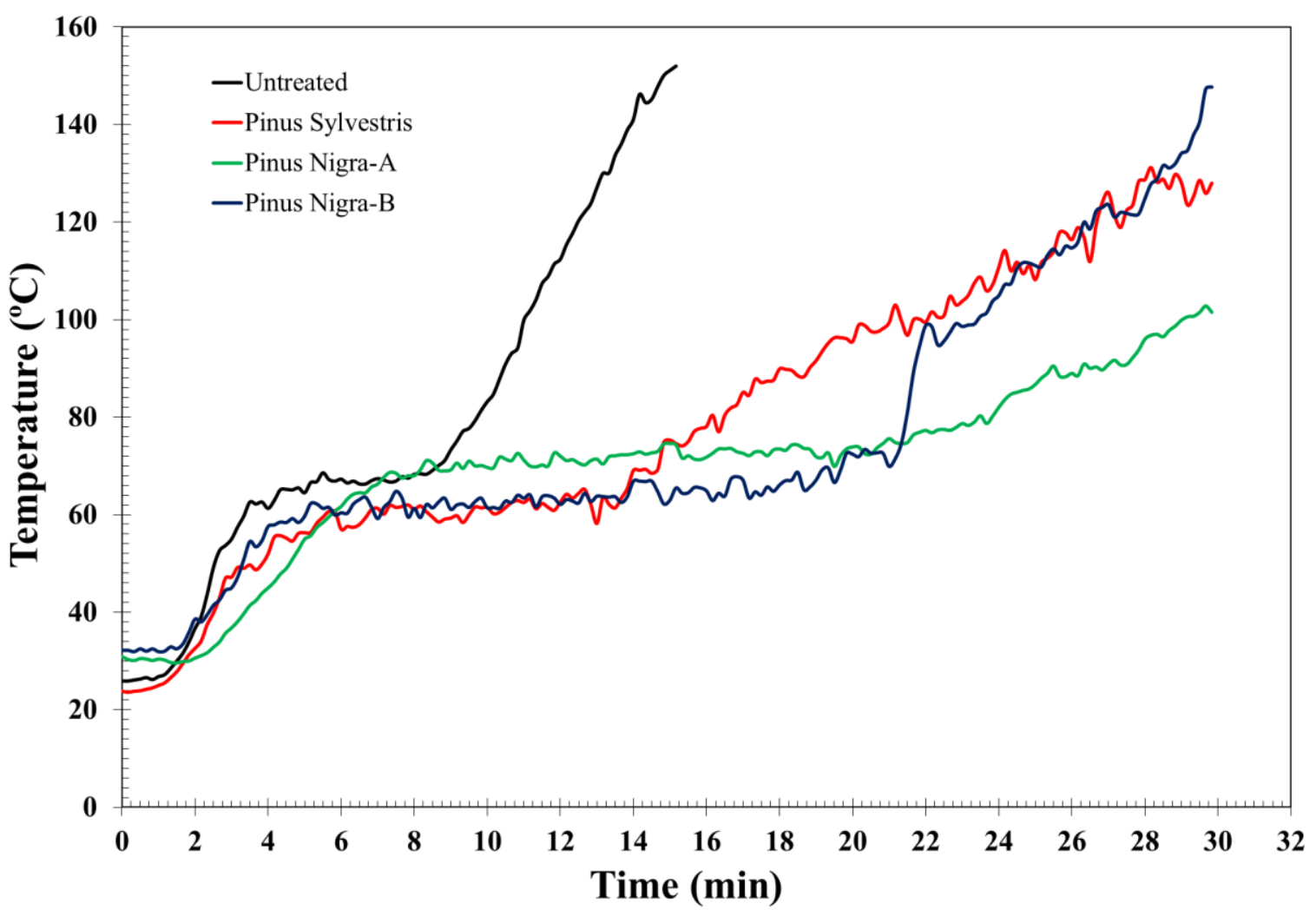

Figure 7. 


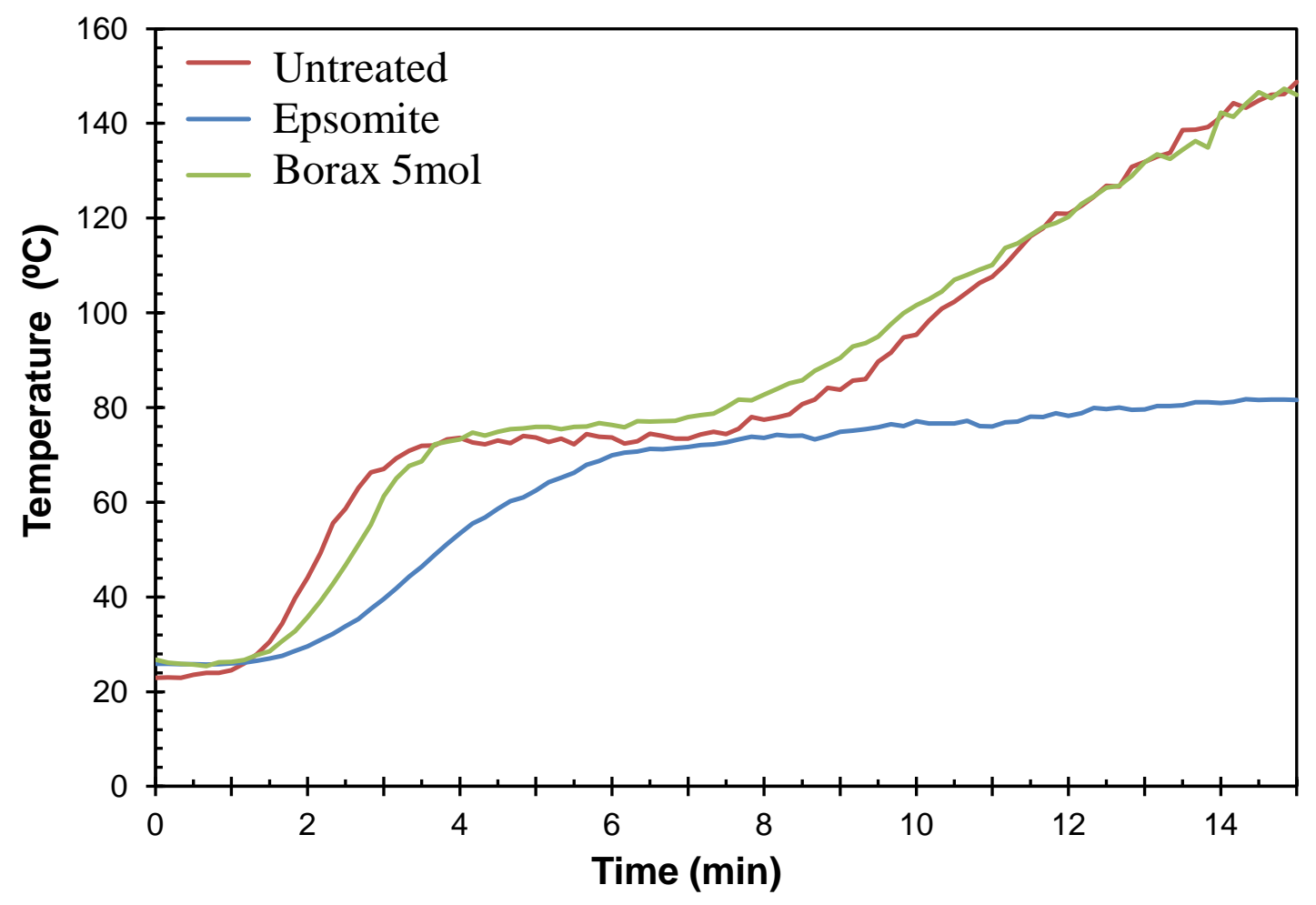

Figure 8. 